\title{
Road as a desiring machine: The development of Lintas Bono Road and Social Transformation in Kampar Peninsula, Riau
}

\section{Fahri Hidayat}

Department of Anthropology, Faculty of Social and Political Science, University of Indonesia. Indonesia. Corresponding author: fahri.hidayat@ui.ac.id

\begin{tabular}{|c|c|}
\hline ARTICLE INFO & ABSTRACT \\
\hline $\begin{array}{l}\text { Keywords: } \\
\text { Development } \\
\text { anthropology; Road } \\
\text { development; social } \\
\text { transformation; desiring } \\
\text { machine; Lintas Bono } \\
\text { Road. } \\
\text { How to cite: } \\
\text { Hidayat, F. Road as a } \\
\text { desiring machine: The } \\
\text { development of Lintas } \\
\text { Bono Road and Social } \\
\text { Transformation in Kampar } \\
\text { Peninsula, Riau. } \\
\text { ETNOSIA: Jurnal } \\
\text { Etnografi Indonesia. } 6(1) \text { : } \\
\text { 217 - 229. } \\
\text { DOI: } \\
\text { 10.31947/etnosia.v6i2.18207 }\end{array}$ & $\begin{array}{l}\text { There is much research on the impact of infrastructure development, } \\
\text { especially road in Indonesia. This in general only focuses on the social } \\
\text { transformation based on the economic changes of the community. } \\
\text { These research show the social transformation as the impact of the road } \\
\text { infrastructure development projects goes beyond economic changes. } \\
\text { Using the perspective of a critical study of development anthropology, } \\
\text { the author discusses the impact of Lintas Bono Road infrastructure } \\
\text { development project in Pelalawan Regency, Riau Province to the social } \\
\text { transformation of the surrounding communities. This study used an } \\
\text { ethnographic method to conduct observations and interviews with the } \\
\text { stakeholders and communities around the Lintas Bono Road } \\
\text { infrastructure development project. This project, which develops by } \\
\text { the Kampar River flow, has changed the communities' transportation } \\
\text { mode, from inland waterway transportation to land transportation. } \\
\text { This change in transportation modes has triggered a social } \\
\text { transformation, where initially the Kampar River coast-including the } \\
\text { villages on the coast-is the main gate ofpeople's lives, then drastically } \\
\text { changed after land transportation access was opened by the } \\
\text { construction of the Lintas Bono Road. The fact that the construction of } \\
\text { this road has not been completed after seventeen years does not make } \\
\text { the community reject this development. The shortcomings and failures } \\
\text { of these developments have actually made the development of this road } \\
\text { as a "desiring machine" for the community to continue to achieve their } \\
\text { development dreams. }\end{array}$ \\
\hline
\end{tabular}

\section{Introduction}

A "noble" ideal to build Pelalawan Regency was initiated by H. Tengku Azmun Jaafar when he served as Regent of Pelalawan Period 2001-20121. With his slogan "Merangkai Kampung Membangun Negeri", Tengku Azmun initiated a prestigious development project, which is a road connecting Pelalawan Regency with Indragiri Hilir Regency,

\footnotetext{
${ }^{1}$ Tengku Azmun Jaafar did not finish his second term as Regent of Pelalawan due to his status as an alleged suspect in corruption case in 2007 by KPK.
} 
Riau Province ${ }^{3}$. The 170-kilometer road crosses many villages and several sub-districts on the coast of Kampar River, Pelalawan Regency, Riau Province. The construction of the road, which began in 2004, has a considerable impact and changes the social conditions of the people it passes through.

Jalan Lintas Bono initiated by former Regent pelalawan H. Tengku Azmun Jaafar was built along the south side of Kampar River. The Lintas Bono Road construction project passes through the villages along the Kampar River in Pelalawan Regency. This road starts from Simpang Bunut (Pangkalan Kuras Sub-district) to Sokoi Village (Kuala Kampar Sub-district).

The construction project is mostly located around peatland that causes difficult operations and takes up a vast sum of 470 billion rupiah budget ${ }^{4}$. The extensive budget amount has made the project status changed from regional development project to provincial development project. The takeover of this road construction project by Riau Province makes its status as a provincial road so that funds for its construction then use the budget from the Riau Provincial Government. In 2020, the construction of the Lintas Bono Road was taken over by the central government and then was included in the National Medium Term Development Plan (RPJMN) 5 . The consequence of this increase in status is that the development of the Lintas Bono Road into a national priority and budgeted in the state budget.

Since the construction began seventeen years ago in early 2004, there are no signs of the Lintas Bono Road will be done in the near future. In 2019 only 50 percent of the construction was built 6 . The latest condition that the author managed to observe on a field visit in April 2021, Lintas Bono Road which has been finely paved - with a few holes in several locations - starting from Simpang Bunut to the Petodaan Village area. Starting from Petodaan Village to Pulau Muda Village, the condition of the road has not been paved and is still in the form of hardening of sand and gravel. The hardened road base has holes along the way. Up to this section, Lintas Bono Road can accommodate four-wheeled to six-wheeled vehicles7. The condition, of the rest of Lintas Bono Road from Segamai Village to the Sokoi Village 8 is a dirt road that has not been hardened with gravel and sand. In this condition the road can not accommodate four-wheeled vehicles. During the rainy season, the condition of this unpaved Lintas Bono Road will be worse and more difficult for vehicles to pass.

As we all know that most development projects are authoritative in nature and unsuccessful. Nevertheless, development projects are done in every part of the world including Indonesia. Lintas Bono Road is one of the many examples of such

\footnotetext{
${ }^{3}$ This information can be found at: http:// riaupotenza.com/berita/27877/15-tahun-jalan-lintas-bono-tak-kunjungkelar

${ }^{4}$ See: https://mediacenter.riau.go.id/read/19876/tahun-ini-pekerjaan-jalan-lintas-bono-diangga.html.

5 See: http:// www.sergaponline.com/read-502-6972-2020-07-09-jalinbon-masuk-rpjmn-dan-jembatan-nilo-dimulaitahun-ini.html.

${ }^{6}$ See: http://riaupotenza.com/berita/27877/15-tahun-jalan-lintas-bono-tak-kunjung-kelar.

7 Six-wheeled vehicles that often pass through the road in this section are trucks carrying palm fruit with diesel engines with a capacity 120-135 ps (mini truck).

${ }^{8}$ The villages that the Lintas Bono Road passes after Pulau Muda Village are Segamai Village, Gambut Mutiara, Labuhan Bilik, Sungai Emas, and Sokoi Village.
} 
development projects and had a significant impact in changing the social condition of the surrounding communities.

At the time this article is written, the Lintas Bono Road which started in 20014 is not done, even not showing signs of completion yet. This fact does not make the communities surrounding the project becoming disaffected, but they insisted to have Lintas Bono Road completed. The expectations and desires of the community which are contrary to the reality in the development project of Lintas Bono Road are explained through the concept of 'desiring machine' from Pieter de Vries (2007) and the concept of modernity and the moral imagination of David Gow (2008).

Lintas Bono Road development project that has been running for seventeen years although it is not done yet - does not make the affected local communities reject the construction of this road, but instead become the hopes and desires of the communities.

In line with de Vries, David Gow (2008) views that development is often forced and does not work, but that does not mean that people do not want development. He assumes that criticism and discussion of development often misses or even deliberately ignores the link between modernity and the wider political, social, and cultural context (Gow, 2008). The presence of the development project of the Lintas Bono Road also gave rise, according to Gow (2008), as a moral imagination in the people of the Kampar River coastal villages in Pelalawan Regency. The moral imagination of these people is not just ideas about what is right and wrong in the development project of the Lintas Bono Road, but their imagination about the ideal development of this road.

\section{- Impact of road infrastructure development on economic and social transformation}

Studies on development have been widely conducted by scholars in Indonesia. The studies also discussed the impact of infrastructure development on the changes of surrounding communities. Studies that discuss the impact of infrastructure development - especially road development - generally focus on economic changes or improving the welfare of the surrounding communities.

The study of infrastructure development - especially roads - conducted by Fajri (2017), Iek (2013), Jasupa et al. (2018), Mustafa and Sasmito (2017), NSS et al. (2015), Ompusunggu (2018), Putri and Buchori (2015), Rahayu and Soleh (2017), and Rahmayana and Handayani (2016) both discussed the impact of such development on social change that is more focused on improving the economy of the community. All studies show that road construction has a positive impact on improving the economy of the surrounding community.

Iek (2013), in his study in the hinterland of May Brat Regency conducted an analysis of the impact of road construction on economic growth and social changes of its people. Iek saw that road construction became a triger of the growth of new jobs outside the agricultural sector so that it became varied. Social changes caused by road construction expressed by Iek are more about the ease of access of the community in utilizing MCK facilities, clean water facilities, lighting, and building materials to build houses (Iek, 2013). 
The study conducted by Fajri (2017) is similar to the Iek (2013). Through his study, Fajri specifically questioned the extent of road infrastructure development to economic growth and welfare of the people of Jenggala Village, Tanjung Subdistrict, North Lombok Regency. From the study, Fajri saw that the construction of roads in this village was able to improve the welfare of its citizens. Not only road construction, welfare improvement in Jenggala Village is also triggered by certain types of work and the level of education of its citizens (Fajri, 2017).

Like Iek, the NSS et al. study (2015) in the form of an analysis of the impact of road construction on growth and economic benefits received by the citizens of Semarang city. An analysis of the impact of road construction conducted by NSS et al. concluded that the construction of road infrastructure has a positive and significant effect on the economic benefits of community economic efforts. When road construction is carried out, the changes that occur in the economy of the community will run in the direction of the development (NSS et al., 2015).

Other studies conducted by Rahmayana and Handayani (2016), Rahayu and Soleh (2017), Mustafa and Sasmito (2017), Jasupa (2018), and Ompusunggu (2018) are similar to the three studies above, namely looking at changes in the economy of the community as a result of road development. However, each of these studies has its own differences.

Mustafa and Sasmito (2017) through their study saw that the implementation of road infrastructure development is the most basic means to support economic development in the form of smooth distribution of goods, as well as community transportation networks. They argue that the welfare of the people in an area can be seen the infrastructure provided by the government (Mustafa \& Sasmito, 2017).

Unlike other studies, the Ompusunggu study (2018) in Semangat Gunung Village, Karo Regency, North Sumatra saw road development not only having a positive impact, but also having a negative impact on the community. The positive impact he encountered was the opening of road access for the community, especially for the wider sale of crops, as well as the opening of more varied jobs. The negative impact expressed by Ompusunggu is that road sidewalks sometimes become a function to be a place to trade, and road maintenance that is not done periodically causes congestion and puddle of water during heavy (Ompusunggu, 2018).

The impact of road construction studied by Jasupa (2015) in Jatak Village, Menyuke Subdistrict, Landak Regency, West Kalimantan is the opening of access for villagers to sell their plantation products outside the village and interact with people from outside their area (Jasupa et al., 2018).

Rahayu and Soleh (2017) and Rahmayana and Handayani's (2016) studies are slightly different from other studies. They examine the impact of infrastructure development in general and not just specific to road development on economic growth. Rahayu and Soleh studied infrastructure development in Jambi Province, while Rahmayana and Handayani studied infrastructure development in Solo Baru, Central Java. Although the objects of development of their studies are different, but the results of the study are similar. Rahayu and Soleh found that the development of infrastructure such as roads and electricity had a positive effect on improving the economy of the communities 
(Rahayu \& Soleh, 2017). Rahmayana and Handayani found that the development of the New Solo Area had a greater impact on the economic changes of the community than on social change (Rahmayana \& Handayani, 2016).

From the various studies that the authors show here, the study from Putri and Buchori (2015) became the most different in terms of the impact of road construction. According to them, the construction of a new road network has an indirect impact on socioeconomics for the surrounding community. When reviewing the construction of the Salatiga Southern Ring Road, Central Java Province, Putri and Buchori found that the development has not significantly affected the changes in socio-economic characteristics of the surrounding communities. This is because the changes only occur in a few locations around the Salatiga Southern Ring Road and are uneven (Putri \& Buchori, 2015).

The above studies are different from the impact of road development of which the author stated in this paper. In general, road developments do have an impact on economic changes of the people living around the area. Furthermore, the social transformation that happened to the peope located around Kampar River, Pelalawan Regency is more significant than the economic change as the result of Lintas Bono Road development. The people living around the Lintas Bono Road project site resonate more with the social change than the economic change due to the development project.

\section{Method}

This paper is based on a research on the livelihood of the people in nine villages alongside Kampar River, Pelalawan Regency, Riau Province. The research is using ethnography methods of which the researcher lived together with the informants during the research while doing interviews and participative observation. The researcher's main focus is the livelihood of the people in the villages where the research took place that is where Lintas Bono Road is contextual to the livelihood of the people in these villages.

The study was conducted on three field trips at different times and locations in different villages. The first field trips were made in June and July 2015 in Teluk Binjai Village, Teluk Meranti Village, Pulau Muda Village, and Segamai Village, in Teluk Meranti Subdistrict. This first field trip was carried out in a total of two months for the four villages. The second field trip was conducted in January and February 2020 in Ransang Village and Sungai Ara Village in Pelalawan Sub-district, as well as Pangkalan Terap Village and Kuala Panduk Village in Teluk Meranti Sub-district. The time of this second field trip is two months for the four villages. The third field trip was conducted in April 2021 for fifteen days in Segamai Village, Teluk Meranti Sub-district.

Informants in this study are stakeholders and residents in each researched village location where the research is related to the livelihoods of the community. These selected informants are people who know the dynamics of livelihood and social transformation well in their respective villages. Data and information about the development of the Lintas Bono Road and the transformation of the surrounding community were obtained from informants in the villages where the research site was made during field trips. Additional information about the construction of the Lintas Bono Road and its development is also obtained from articles and news in newspapers. 


\section{Result and discussion}

\section{- Social transformation brought by Lintas Bono Road development project}

Momose (2002) in his study in the Kampar Peninsula region found seventeen villages located in the main stream and branches of the Kampar River. He divided the villages in the Kampar Peninsula region into four types, namely pangkalan villages, muara villages, migrant villages, and fishing villages (Momose, 2002). The pangkalan village referred to by Momose (2002) is a villages located in the branch stream of the Kampar River in the foothills and serves as a port that connects trade from hills to the main trade routes on the Kampar River. Villages categorized by Momose as pangkalan villages can be characterized by one of them - although not always - through the name of the village, such as Pangkalan Bunut and Pangkalan Panduk Village. Muara village according to Momose (2002) are river port villages located at the confluence of branch rivers with Kampar River. People on the coast of the Kampar River refer to the region as kuala or teluk. These Muara villages can generally be characterized - apart from their location as well as from the names used, such as Kuala Tolam, Kuala Panduk, and Teluk Meranti Village. Some villages, located on the banks of the main stream of the Kampar River and not located at the confluence with branch streams, are classified by Momose (2002) as migrant villages. The villages categorized by Momose as migrant villages are Pulau Muda Village, Segamai, and Labuhan Bilik ${ }^{9}$. The fourth category of Momose (2002) is a fishing village that is outside the peat swamps area. Villages that are categorized as fishing villages - or bagan villages according to terms in Kampar River coast - one of them is Penyalai Village located on Mendol Island, Kuala Kampar Subdistrict.

The villages along the Kampar River have characteristics like the coastal villages of the river in Sumatra in general. For several centuries, rivers in the East Sumatra region including the Kampar River - have been important trade routes connecting agricultural communities in the hinterland of Sumatra Island with the world outside the Strait of Malacca (Momose, 2002). Kampar River which is an important trade route in addition to connecting the central mainland area of Sumatra Island with the area around the Malacca Strait, also includes the area in between. As a trade route, the main mode of transportation of these villages along the Kampar River is the transportation of water through this river (Momose, 2002). (Momose, 2002)The Kampar River as the main of transportation and trade route of citizens, being the front or main gate of these villages - the category one through three of villages from Momose.

Before the construction of Lintas Bono Road project, the daily transportation of residents of Kampar River coastal villages was waterway transportation through this river. This is the heyday of water transportation on the Kampar River. Every day there is a speedboat that serves the Pangkalan Kerinci-Tanjung Batu city route (round-trip) as

\footnotetext{
${ }^{9}$ To explanation more continued category third called as village migrant by Momose get see Writing that Titled "Environments and People of Sumatran Peat Swamp Forests II: Distribution of Villages and Interactions between People and Forests" year 2002.
} 
public transportation ${ }^{10}$. This public transportation passes through the Kampar River, including villages along this river.

Villages located on the coast of main stream Kampar River - muara villages and migrant villages according to the Momose category - became the main villages in transportation and trade routes. At that time, these villages were considered much more advanced than villages that were located more ashore and not on the main stream of the Kampar River or pangkalan villages according to the Momose category. At that time the villages that were not located on the main stream of the Kampar River were considered isolated villages,even some residents dubbed it a "pedalaman villages". The economy of the villages on the coast of the Kampar River is also considered more advanced than these pedalaman villages. To meet daily needs - other than agriculture - residents of these pedalaman villages must go and buy them at the market of the coastal village of Kampar River on market day ${ }^{11}$. The economic commodities sold in the markets of the coastal villages of Kampar River are more complete than the pedalaman villages.

In addition to public transportation, Kampar River is also the main line of commodity chains in the region. Villagers sell their agricultural products ${ }^{12}$ to tauke-tauke ${ }^{13}$ who come from Tanjung Batu City and the areas around Riau Islands. These tauke came to the coastal villages of Kampar River to collect and buy the products of the citizens using tambang boats. ${ }^{14}$ In the period before 2017, residents of coastal villages do not have to bother bringing their products outside the village to sell it. The tauke who came to the coastal villages of Kampar River to buy the products of the residents. Residents in pedalaman villages also bring their agricultural products to the coastal village of Sungai Kampar (kuala villages) nearby to be sold to tauke who come there.

In terms of the physical development of the village, the characteristic of the coastal villages of Sungai Kampar is the pattern of settlement and development that is oriented to the river. The construction of the village overlooks the Kampar River as the main gate of the village. The construction of ports, market, office and village hall, mosques, and houses of residents is centered along the river and facing the Kampar River. Locations that are far from the Kampar River and more on inland are allocated for the needs of the kebun and ladang of the residents. The location of these kebun and ladang is considered the backsides of the village.

Since the construction of Lintas Bono Road in 2004, gradually there has been a social transformation in the villages along the Kampar River. The Lintas Bono Road development project provides an alternative access for communities in the region. This road development project opened road access to many coastal villages of Kampar River. The Lintas Bono Road also "opened the eyes" of the people in the region, which made

\footnotetext{
10 Tanjung Batu City is a city located on Kundur Island, Riau Islands Province which is the closest city to the Peninsula Kampar region. In the heyday of waterway transportation on the Kampar River, the city became a main destination residents of Kampar Peninsula villages to travel and vacation to the city.

${ }_{11}$ Market in villages at Kampar Peninsula only open once a week. People in these villages refer to the market with the local term, namely pekan. The market day for each nearby village is different.

12 The agricultural products that become commodities for residents in the villages in general are oil palm, rubber, and coconut.

13 The local's term for collectors and buyers of agricultural products sold by residents, see Amady (2014).

14 The local's name for wooden ships used as transporters of merchandise. This wooden ship is diesel engined with a fairly varied capacity.
} 
them have a new view that they have been living in low-access and isolated conditions, where this view did not exist in the period before the construction of the Lintas Bono Road. ${ }^{15}$

Around 2017, Lintas Bono Road can be accessed by four-wheel and six-wheel vehicles from Simpang Bunut to Pulau Muda village all year round (rainy and dry season) ${ }^{16}$. This new road transportation access gave a cheap, and fast transportation alternative other than the waterway transportation that they used. This phenomenon disrupted the stability of the dominant waterway transportation. Public road transportations grew more and impacted the dominance of waterway transportation. The village people altered their transportation mode to road transportation to do their errands. The peak of this phenomenon happened around 2017 when the public waterway transportations that connect Pangkalan Kerinci and Tanjung Batu city stopped their operation for good. The remaining river transportation is public speedboats that operate from Pulau Muda village to Tanjung Batu city (roundtrip). The reason this route is still operating is that the section of the Lintas Bono Road from Pulau Muda village to Sokoi village can not accommodate four-wheel vehicles. Moreover, the people still need river transportation to reach Tanjung Batu city on Riau Islands Province. This is why waterway transportation is still the only option available for the villages from Segamai village to Sokoi village as the access of their villages.

Another change that happens due to the Lintas Bono Road development is the settlement and development pattern in the village. Settlement and villages developments along Kampar River are no longer orientated to the river. Residents in villages whose administrative areas passed by Lintas Bono Road began to move and build their homes to this edge. Many trading centers have been "moved" to the side of the Lintas Bono Road. Some villages have even planned to move the location of the village office and market from Kampar Riverside to the side of Lintas Bono Road.

The people who live alongside Lintas Bono Road start to sell their land properties to other local villagers and other people outside the villages. Land sales around Lintas Bono Road bring two impacts. First, it increases the price of the land alongside Lintas Bono Road compare to the other land in other locations. Second, the selling attracts people from outside the village communities to come and live in these villages. These people come from the neighboring villages and also from other areas from Riau Province, even from outside Riau Province. The large number of people who come and live in the villages alongside Lintas Bono Road come from various ethnic groups which change the ethnic compositions in those villages. Most of the people are Javanese and Bataknese ethnicities - asides from other ethnicities - who then come and live in the villages along the Lintas Bono Road since the development project started. On the contrary, other villages located in the Kampar River coast of which territories are not passed by Lintas

\footnotetext{
15 Public views on this matter were obtained during the research conducted at the research location.

${ }^{16}$ In the author's first field visit in 2015, the Bono Cross Road which can be passed by four to six-wheeled vehicles throughout the year only reaches Teluk Meranti Village. From Teluk Meranti Village to Pulau Muda Village, the vehicle can only be passed during the dry season.
} 
Bono Road do not have much different ethnic composition compare to the other villages that are located around the Lintas Bono Road. ${ }^{17}$

Another impact of Lintas Bono Road is the trading pattern change on the commodity chain on the Kampar River coast. The road is an alternative to the community local produce trading. Tauke, a common term used to refer to business owners or buyers, comes to buy the local produce from the villagers. These taukes have become increasingly diverse since the road construction began. This is considered to benefit the residents because the prices offered by the tauke are more varied - although in reality this is not always the case. Taukes from Sorek (an area in the Lintas Timur Sumatera road) and Bunut, who start to come through Lintas Bono Road, offer higher prices than before when buying the local produce. On the other side, taukes from Kota Tanjung Batu and Riau Islands area are beginning to subsided and not many of them coming to these villages ${ }^{18}$. Taukes from Tanjung Batu and Riau Islands still come and trade with the villagers of Segamai, Gambut Mutiara, Labuhan Bilik, Sungai Emas, and Sokoi due to the dirt road section of Lintas Bono Road.

The obvious impact of Lintas Bono Road access is the concept of pedalaman village concept that is known by the communities. Since the road access is open, pangkalan villages located far from the Kampar riverside are no longer considered as pedalaman villages. These villages become the front line villages because they are located by the roadside of Lintas Bono Road and gain the advantages of the road access opening. On the other, the villages on the Kampar riverside like desa kuala, which was the front line village when the waterway is the dominant transportation mode, has a 180 degree turn of fate after Lintas Bono Road constructed. The villages on the coast of Kampar River which are not passed by Lintas Bono Road turn to the pedalaman villages ${ }^{19}$. These villages' status is increasingly attached as the pedalaman villages because their location is remotely located from Lintas Bono Road. Adding to that, these villages do not have road access to Lintas Bono Road ${ }^{20}$.

What happened to the communities around the Lintas Bono Road development project as, what Bovensiepen and Yoder (2018) called, the impact caused by the Mega development project. Bovensiepen and Yoder revealed that mega development projects not only have an impact after completion, but also have an impact before and during the development process (Bovensiepen \& Yoder, 2018). The social transformation of the communities around the Lintas Bono Road development project described above, occurred during the road construction process.

\footnotetext{
${ }^{17}$ Data and information regarding the composition of these ethnic groups were obtained from interviews with informants and observations during the study at the research location. From the results of this interview, many of these ethnic groups came after the Lintas Bono Road was constructed.

${ }^{18}$ The Lintas Bono Road that passes through these villages can be passed by four-wheeled vehicles

${ }^{19}$ Sungai Ara and Pangkalan Terap village are two examples of villages whose fate changed 180 degrees from the frontline village when the main transportation route was the river, to becoming an "pedalaman village" when the Lintas Bono Road was built. The settlement area of these two villages are not directly crossed by the Lintas Bono Road and are about a few kilometers away (about 8.3 kilometers from the Lintas Bono Road to the Sungai Ara village settlement and about twelve kilometers to the Pangkalan Terap village settlement).

${ }^{20}$ The Pangkalan Terap village, apart from having a long distance from the Lintas Bono Road, also does not have road access to the Lintas Bono Road. Pangkalan Terap village residents who want to go to Lintas Bono Road must use a boat or speedboat to Kuala Panduk Village and continue the journey by using vehicles such as motorcycles or cars.
} 


\section{- To whom Lintas Bono Road is?}

The Lintas Bono Road development project not only passes through the coastal villages of Kampar River, but also passes through several company-owned concession areas and "hak guna usaha" (HGU) ${ }^{21}$. This condition shows that the beneficiaries of the Lintas Bono Road is not only the villagers along this road, but also the company whose concession and HGU areas are around this road. The company's vehicles pass through this road to get to the company. Is this Lintas Bono Road development project intended for the needs of the communities, or from the beginning this project is intended as a support for investment in this region?

It is inevitable that most the people in the communities get the benefit from Lintas Bono Road. Ombak Bono tourist destination can be developed after the road is built. Local and foreign tourists can easily go to Ombak Bono through Lintas Bono Road. To the communities living in the Kampar River coastal area, road transportation is cheaper and faster compared to waterway transportation. Local taukes in the village can transport their commodities faster and cheaper through Lintas Bono Road. Traders from Bunut and Sorek can reduce their traveling time and cost when they come to the villages on the Kampar River coastal area to do trading on the market day.

Beyond that, companies that have concession and HGU areas around Lintas Bono Road also benefit. The mobility of employees to and from these companies becomes easier, faster and cheaper through Lintas Bono Road. These companies generally do have their own roads in the concession or HGU areas that they specifically build for the company's operational purposes. However, these companies can still take benefit of the access provided by Lintas Bono Road. Lintas Bono Road also makes it easier for these companies to make contact with the villagers crossed by this road in the framework of the implementation of corporate social responsibility or other needs.

\section{- 'Never ending development' of Lintas Bono Road as a 'desiring machine'}

When the author wrote this paper it has been seventeen years of Lintas Bono Road's development since it began in 2004. During this long period, the development has not done yet and it has not shown any signs of completion. The construction progress is also varied in every village. Some villages have good and open access - on the the section of Lintas Bono Road has been hardened and covered with asphalt - meanwhile, other villages have not got the same opportunity.

The different construction progress that happens has become a dilemma for the communities, especially for those whose area has the unfinished section of Lintas Bono Road. They viewed their villages as isolated and undeveloped because of the unfinished section of the road ${ }^{23}$. The road has become a monument of their village development. They compare the progress to other villages around the Lintas Bono Road development

\footnotetext{
${ }^{21}$ There are several industrial forest plantations (HTI) and oil palm companies whose areas are around Lintas Bono road.

${ }^{23}$ Segamai village, Gambut Mutiara, Labuhan Bilik, Sungai Emas, and Sokoi.
} 
project. The contrast condition of the progress has made them want the same condition as other villages.

The villages with the unfinished section of Lintas Bono Road have not got access to road transportation. They are still using waterway transportation which in their view is more expensive and takes more time. Regarding trade, they think that the villages with access to Lintas Bono Road are more developed. In their perspective, the people from these villages can easily sell their products at higher and competitive prices because there are many taukes to trade with. Furthermore, these villages can easily fulfill their economic needs because there is a fast and easy economic supply through access to road transportation.

The above conditions show that the Lintas Bono Road development project becomes as, mentioned by Pieter de Vries (2007) as a 'desiring machine' and also moral imagination according to David Gow (2008). Pieter de Vries (2007) saw the 'desiring machine' as a continuous effort in carrying out development that stemmed from the failures and shortcomings of development itself. The failure and lack of development is actually the fuel in activating other development projects. This then makes development as a 'desiring machine' that produces endless desire (de Vries, 2007).

Lintas Bono Road's development project became a 'desiring machine' that generated endless desire from villagers along the coast of the Kampar River. The unfinished Lintas Bono Road development project can be considered a failure and shortcoming of the development project in question. The failures and shortcomings felt by the community from the Lintas Bono Road development project are precisely the fuel for their development dream, namely the existence of good road access to the communities. The "inequality" felt by people in villages that have not felt the development of Lintas Bono Road well raises hopes and dreams so that they can feel the same progress as other villages.

In line with de Vries, David Gow (2008) views that development is often forced and unsuccessful, but that does not mean that people do not want development. This is corroborated by the opinion of Jonathan Crush (Crush, 1995) that development has lost its appeal and popularity, but like it or not, development continues. Gow (2008) assumes that criticism and discussion of development often misses or even deliberately ignores the link between modernity and the wider political, social, and cultural context (Gow, 2008). Gow sees modernity as different from modernization which is generally simplisistis and mechanical.

The presence of the Lintas Bono Road development project also gave rise, according to Gow (2008) a moral imagination, in the community of Kampar River coastal villages in Pelalawan Regency. This moral imagination is not just ideas about what is right and wrong, but imagination about the ideal concept of the Lintas Bono Road. People there have an ideal concept of the development of this road based on how they feel from the presence of Lintas Bono Road and then compared to the conditions outside the village, even in areas far outside their village. This moral imagination is not formed by itself, but is formed because of its relation to modernity. This material form of development in the 
form of the Lintas Bono Road is considered part of modernity which then creates people's hopes and dreams about what the village they consider modern.

\section{Conclusion}

In the period before the Bono Cross Road construction project, residents in villages along the Kampar River were accustomed to waterway transportation. At that time the Kampar River became the main gate of people's lives. The daily life of the people in this area cannot be separated from the river itself. They never felt any objection to using waterway transportation. Not only as the main route of transportation, the Kampar River is also the main route of community trade. The residents of these villages also do not feel that their village is isolated and left behind. In fact, residents from villages that were far inland and far from the coast of the Kampar River felt isolated because they were far from the main transportation access at that time.

Since the commencement of the Lintas Bono Road development project, the condition of the villages along the Kampar River has changed and turned upside down. The social transformation of the communities around Lintas Bono Road is starting to take place. Kampar Riverside village which was once the "main gate" or "front door" of people's lives has turned into a "back door". On the other, villages located on land and some distance from the Kampar River turned into "front doors" after the development of the Lintas Bono Road. Villagers along the Kampar River began to have comparisons about which conditions were considered more ideal and which were not. Residents who live in riverside villages - especially those who have not had road access to the Bono Cross Road - are isolated and feel that their villages are left behind. When residents encounter this opposite condition, they begin to crave and create a moral imagination for a development that is given from outside. The dream of community development along the Kampar River is the construction of a road infrastructure - Lintas Bono Road - which later becomes their desiring machine.

Aknowledgement:

The author would like to thank Suraya A. Afiff, Ph.D. and Mia Siscawati, Ph.D. who has provided a critical thinking framework in the study of development anthropology at the Graduate School of Anthropology, University of Indonesia. The author would also like to thank the key informants in the research villages who helped the author in conducting field visits.

Conflicts of Interest:

"The author declare no conflict of interest." The research conducted by the author in three field visits was in the context of the work of the institution where the author worked at that time. The author wrote this article for the needs of a graduate school in the Department of Anthropology, Faculty of Social and Political Sciences, University of Indonesia. The data used in this article is data taken by the author himself. The institution where the author has worked has known and given permission for the use of the data, so "The institution had no role in the design of the ideas; in the collection, analyses, or interpretation of data; in the writing of the manuscript, and in the decision to publish related to this article". 


\section{References}

Amady, M. R. L. (2014). Tauke dan Budaya Hutang: Perubahan Sosial Budaya pada masyarakat Desa (1st ed.). AG Litera.

Bovensiepen, J., \& Yoder, L. S. M. (2018). Introduction: The Political Dynamics and Social Effects of Megaproject Development. Asia Pacific Journal of Anthropology, 19(5), 381394. https://doi.org/10.1080/14442213.2018.1513553

Crush, J. (1995). Power of development. In Jonathan Crush (Ed.), Power of development. Routledge. https://doi.org/10.2307/144452

de Vries, P. (2007). Don't compromise your desire for development! A Lacanian/Deleuzian rethinking of the anti-politics machine. Third World Quarterly, 28(1), 25-43. https:// doi.org/10.1080/01436590601081765

Fajri, L. M. N. (2017). Pengaruh Pembangunan Infrastruktur Jalan Terhadap Peningkatan Ksejahteraan Masyarakat Desa (Studi Kasus di Desa Jenggala Kecamatan Tanjung Kabupaten Lombok Utara). Jurnal SIKAP, 1(1), 11-22. http:/ / ejournal.unwmataram.ac.id/sikap/article/view/134

Gow, D. D. (2008). Countering Development: Indigenous Modernity and the Moral Imagination. Duke University Press.

Iek, M. (2013). Analisis Dampak Pembangunan Jalan Terhadap Pertumbuhan Usaha Ekonomi Rakyat di Pedalaman May Brat Provinsi Papua Barat (Studi Kasus di Distrik Ayamaru, Aitinyo dan Aifat). Jurnal Ekonomi Kuantitatif Terapan, 6(1), 30-40. https://ojs.unud.ac.id/index.php/jekt/article/view/4510

Jasupa, A., Zakso, A., \& Salim, I. (2018). Analisis Dampak Sosial Pembangunan Jalan Di Dusun Jatak Kecamatan Menyuke Kabupaten Landak. Jurnal Pendidikan Dan Pembelajaran Khatulistiwa, 7(3), 1-11. http://jurnal.untan.ac.id/index.php/jpdpb/article/view/24491

Momose, K. (2002). Environments and People of Sumatran Peat Swamp Forests II: Distribution of Villages and Interactions between People and Forests. Southeast Asian Studies, 40(1), 87-108. https://kyoto-seas.org/2011/02/southeast-asianstudies-vol-40-no-1/

Mustafa, M., \& Sasmito, C. (2017). Implementasi Pembangunan Infrastruktur Jalan Desa. JISIP: Jurnal Ilmu Sosial Dan Ilmu Politik, 6(3), 72-76. https:// doi.org/10.33366/jisip.v6i3.1462

NSS, L. P., Suryawardana, E., \& Triyani, D. (2015). Analisis Dampak Pembangunan Infrastruktur Jalan Terhadap Di Kota Semarang. Jurnal Dinamika Sosial Budaya, 17(2), 82-103. https:// doi.org/10.26623/jdsb.v17i1.505

Ompusunggu, V. M. (2018). Dampak Pembangunan Infrastruktur Jalan Terhadap Pertumbuhan Ekonomi Masyarakat Di Desa Semangat Gunung, Kabupaten Karo, Sumatera Utara. Journal Pendidikan Ekonomi, 3(2), 18-26. https://doi.org/10.29100/jupeko.v3i2.870

Putri, M. B., \& Buchori, I. (2015). Pengaruh Pembangunan Jalan Lingkar Selatan Salatiga Terhadap Perubahan Karakteristik Sosial Ekonomi Penduduk di Sekitarnya. Jurnal Pembangunan Wilayah \& Kota, 11(2), 222-241. https://doi.org/10.14710/pwk.v11i2.10850

Rahayu, Y., \& Soleh, A. (2017). Pengaruh Pembangunan Infrastruktur terhadap Pertumbuhan Ekonomi Provinsi Jambi (Pendekatan Fungsi Cobb Douglas). Jurnal Development, 5(2), 125-139. https://doi.org/https:/ / doi.org/10.53978/jd.v5i2.52

Rahmayana, L., \& Handayani, W. (2016). Transformasi Sosial Ekonomi Penduduk Lokal Akibat Adanya Pembangunan Di Kawasan Solo Baru Kabupaten Sukoharjo. Teknik PWK (Perencanaan Wilayah Kota), 5(3), 174-185. https://ejournal3.undip.ac.id/index.php/pwk/article/view/17900 